\title{
BIOCHEMICAL STUDIES RELATED TO ACUTE CHOLECYSTITIS IN LIBYAN SUBJECTS
}

\author{
Abdalla M Jarari ${ }^{1}$, Abdelaziz MA AlFaydi ${ }^{1}$, Nouh MH Aljarari ${ }^{2}$, Saeid Omar Al \\ Soaeiti ${ }^{3}$, Ibtisam Cheith Kaziri ${ }^{1}$, Dhastagir Sultan Sheriff ${ }^{* 1}$ 伲 (iD) \\ ${ }^{* 1}$ Department of Biochemistry, Benghazi University, Benghazi, Libya \\ 2 Department of Pharmacology, Benghazi University, Benghazi, Libya \\ ${ }^{3}$ Department of Surgery, Benghazi University, Benghazi, Libya
}

DOI: https://doi.org/10.29121/granthaalayah.v8.i8.2020.1005

Article Type: Research Article

Article Citation: Abdalla M Jarari, Abdelaziz MA AlFaydi, Nouh MH Aljarari, Saeid Omar Al Soaeiti, Ibtisam Cheith Kaziri, and Dhastagir Sultan Sheriff. (2020).

BIOCHEMICAL STUDIES RELATED TO ACUTE CHOLECYSTITIS IN LIBYAN SUBJECTS. International Journal of Research -

GRANTHAALAYAH, 8(8), 226-232. https://doi.org/10.29121/granthaa layah.v8.i8.2020.1005

Received Date: 06 August 2020

Accepted Date: 29 August 2020

Keywords:

Biochemical Studies

Acute Cholecystitis

Libyan Subjects

\section{ABSTRACT}

Acute cholecystitis and cholelithiasis are one of common health problems of Libyans. [1] Acute cholecystitis or bile gallbladder stones are one of the major surgical problems in the Libyan population and account for many hospital admissions and surgical interventions. This study was done to estimate causes and risk factors of $\mathrm{AC}$ among general population of Benghazi city in Libya. Reflux of pancreatic secretions into the biliary duct due to a defect in motility of gallbladder or biliary tree or spastic episodes of Sphincter Oddi may cause injury to gallbladder mucosa and biliary tract which may precipitate acute cholecystitis. Pancreatic biliary reflux (PBR) therefore may cause such reflux of pancreatic juice into gallbladder and biliary tract. This problem is probably related to obesity, cardiovascular disorders (CVD), metabolic syndrome, and dietary habits. Studies on gallstone composition carried out a close link with dietary habits and ethnicity. The biliary composition has been demonstrated by many researches for several years. Gallstone formation is relatively increased with consumption of dietary fats, age and gender.2-3 Estimation of pancreatic amylase in gallbladder bile as well as in serum of patients with acute cholecystitis (AC) may be considered as a biomarker of PB reflux. Serum and bile pancreatic amylase levels as marker for diagnosis of acute cholecystitis" by investigate biliary composition especial alpha amylase pancreatic, total amylase, liver enzymes estimation the correlation between (AST, ALT, ALP and Bilirubin total, C-RP and lipid profile in gallstone disease patients and estimate the correlation between (Cholesterol, HDL, LDL, VLDL) concentration in serum and biliary gallbladder, presence of gallstones, age, in both gender patient with gallbladder diseases.

\section{INTRODUCTION}

Acute cholecystitis and cholelithiasis are one of common health problems of Libyans. [1] Acute cholecystitis or bile gallbladder stones are one of the major surgical problems in the Libyan population and account for many hospital admissions and surgical interventions. This study was done to estimate causes and risk factors of AC among general population of Benghazi city in Libya. Reflux of pancreatic secretions into the biliary duct due to a defect in

(C) 2020 The Author(s). This is an open access article distributed under the terms of the Creative Commons Attribution License, which permits unrestricted use, distribution, and reproduction in any medium, provided the original author and source are credited. 
motility of gallbladder or biliary tree or spastic episodes of Sphincter Oddi may cause injury to gallbladder mucosa and biliary tract which may precipitate acute cholecystitis. Pancreatic biliary reflux (PBR) therefore may cause such reflux of pancreatic juice into gallbladder and biliary tract. This problem is probably related to obesity, cardiovascular disorders (CVD), metabolic syndrome, and dietary habits. Studies on gallstone composition carried out a close link with dietary habits and ethnicity. The biliary composition has been demonstrated by many researches for several years. Gallstone formation is relatively increased with consumption of dietary fats, age and gender. [2], [3] Estimation of pancreatic amylase in gallbladder bile as well as in serum of patients with acute cholecystitis (AC) may be considered as a biomarker of PB reflux. Serum and bile pancreatic amylase levels as marker for diagnosis of acute cholecystitis" by investigate biliary composition especial alpha amylase pancreatic, total amylase, liver enzymes estimation the correlation between (AST, ALT, ALP and Bilirubin total, C-RP and lipid profile in gallstone disease patients and estimate the correlation between (Cholesterol, HDL, LDL, VLDL) concentration in serum and biliary gallbladder, presence of gallstones, age, in both gender patient with gallbladder diseases.

\section{MATERIALS AND METHODS}

Twelve hours fasting overnight venous blood samples were collected from (103) acute cholecystitis cases, undergoing elective open or laparoscopic cholecystectomy. Simultaneously, the anesthesiologist obtained a (5) ml sample of venous blood from a peripheral vein blood was collected in ethylene di amine tetra acetic acid (EDTA) and plain tubes. After removing the needle, the blood was allowed to clot for at least (10-15) min at room temperature then serum was separated by centrifugation at $3000 \mathrm{rpm}$ for 15 minutes. In addition, carefully transferred to plastic tubes and stored at $2-8{ }^{\circ} \mathrm{C}$ for 24 hours prior to assay. Serum samples were either analyzed immediately or stored at $-20{ }^{\circ} \mathrm{C}$ until they were analyzed for further use.

The bile gallbladder samples were collected from patients (103) had acute cholecystitis, undergoing elective open or laparoscopic cholecystectomy remove gallbladder during surgery, before initiating the dissection of the Calot's triangle $5 \mathrm{ml}$ of bile obtained from the gallbladder using a sterile syringe were stored at $4-8^{\circ} \mathrm{C}$, and analyzed for pancreatic alpha amylase, total amylase, lipid profile, C- reactive protein and liver enzyme within a week. The biliary and serum samples were kept at room temperature $\left(21-25.8^{\circ} \mathrm{C}\right)$, delivered for processing and analysis within 2 hrs.

\section{RESULTS}

From the results it is observed mean values \pm SD of the study group included 103 patients with a mean age and \pm SD were $33.75 \pm 6.66$. There were 94 (91\%) females; the mean $\& \pm$ SD of age were $32.78 \pm 6.14$. There were $9(8 \%)$ males had gallstone; the mean $\& \pm$ SD of age were $43.89 \pm .92$. Females were had gallstones $86(83 \%)$ of total cases, the mean $\& \pm$ SD of age were $31.94 \pm 5.74$. females more than 40 aged (41.75 \pm .46$)$.

Table 1: Show the mean value and \pm SD of age in year, number of cases and its percentage (\%), in groups studied.

\begin{tabular}{|c|c|c|c|}
\hline Group & Age & No of cases & Cases $\%$ \\
\hline All cases & $33.75 \pm 6.66$ & 103 & $100 \%$ \\
\hline Female & $32.78 \pm 6.14$ & 94 & $91 \%$ \\
\hline Male & $43.89 \pm .92$ & 9 & $9 \%$ \\
\hline Age $>40$ & $42.88 \pm 1.31$ & 17 & $16 \%$ \\
\hline Female had stone $<40$ & $31.94 \pm 5.74$ & 86 & $83 \%$ \\
\hline Female had stone $>40$ & $41.75 \pm .46$ & 8 & $8 \%$ \\
\hline
\end{tabular}

Pancreatic alpha amylase concentrations in bile gallbladder were significantly higher than in serum of all patients $(23.44 \pm 22.81 \mathrm{U} / \mathrm{l}$ for bile, $32.16 \pm 11.07 \mathrm{U} / \mathrm{l})$ and $\mathrm{p}=(0.000)$. 
Table 2: Show the mean value \pm SD of pancreatic alpha amylase $(U / \mathrm{l})$, and total amylase $(\mathrm{U} / \mathrm{l})$, in bile gallbladder of all patients' cases.

\begin{tabular}{|c|c|c|c|}
\hline Parameter & $\begin{array}{c}\text { Bile } \\
\mathrm{n}=103\end{array}$ & $\begin{array}{c}\text { Serum } \\
\mathrm{n}=103\end{array}$ & $\rho$ value \\
\hline Pancreatic $\alpha$-Amylase $(\mathrm{U} / \mathrm{l})$ & $23.44 \pm 22.81$ & $32.16 \pm 11.07$ & 0.000 \\
\hline Total amylase $(\mathrm{U} / \mathrm{l})$ & $13.85 \pm 8.90$ & $45.18 \pm 13.32$ & 0.000 \\
\hline
\end{tabular}

The mean concentration of bile pancreatic alpha amylase was significantly higher than serum pancreatic alpha amylase. The mean concentration of serum total amylase was significantly higher than bile total amylase. $\rho$ Value (0.000).

Table 3: Show the mean value \pm SD of lipid profile TC, TG, HDL, LDL, VLDL cholesterol (mg/dl) in bile and serum of all patients' cases.

\begin{tabular}{|c|c|c|c|}
\hline Parameter & $\begin{array}{c}\text { Bile } \\
\mathrm{n}=103\end{array}$ & $\begin{array}{c}\text { Serum } \\
\mathrm{n}=103\end{array}$ & $\rho$ Value \\
\hline $\mathrm{TC}(\mathrm{mg} / \mathrm{dl})$ & $135.71 \pm 102.73$ & $145.60 \pm 30.83$ & .000 \\
\hline $\mathrm{TG}(\mathrm{mg} / \mathrm{dl})$ & $110.89 \pm 89.17$ & $97.57 \pm 33.10$ & .000 \\
\hline HDL-C(mg/dl) & $31.25 \pm 27.83$ & $36.76 \pm 16.52$ & .000 \\
\hline LDL-C $(\mathrm{mg} / \mathrm{dl})$ & $126.60 \pm 121.12$ & $85.17 \pm 23.58$ & .000 \\
\hline VLDL-C(mg/dl) & $17.14 \pm 12.03$ & $19.36 \pm 6.53$ & .000 \\
\hline
\end{tabular}

The mean concentration of bile TC was significantly higher than serum TC. The mean concentration of bile TG was significantly higher than serum TG. The mean concentration of bile HDL cholesterol was significantly higher than serum HDL cholesterol.

The mean concentration of bile LDL cholesterol was significantly higher than serum LDL.The mean concentration of bile VLDL cholesterol was significantly higher than serum VLDL. $\rho$ Value $(0.000)$.

Table 4: Correlation of lipid profile TC, TG, HDL, LDL, and VLDL cholesterol (mg/dl) in serum of all patient's cases.

\begin{tabular}{|c|c|c|c|c|c|c|c|c|c|c|}
\hline \multirow{2}{*}{ Parameter } & \multicolumn{2}{|c|}{ S-CHOL } & \multicolumn{2}{c|}{ S-TG } & \multicolumn{2}{c|}{ S-HDL-C } & \multicolumn{2}{c|}{ S-LDL-C } & \multicolumn{2}{c|}{ S-VLDL } \\
\cline { 2 - 12 } & $\mathrm{r}$ & $\mathrm{P}-\mathrm{V}$ & $\mathrm{r}$ & $\mathrm{P}-\mathrm{V}$ & $\mathrm{r}$ & $\mathrm{P}-\mathrm{V}$ & $\mathrm{r}$ & $\mathrm{P}-\mathrm{V}$ & $\mathrm{r}$ & $\mathrm{P}-\mathrm{V}$ \\
\hline S-CHOL (mg/dl) & 1 & & $.957^{* *}$ & .000 & $.993^{* *}$ & .000 & $.994^{* *}$ & .000 & $.954^{* *}$ & .000 \\
\hline S-TG (mg/dl) & $.957^{* *}$ & .000 & 1 & & $.956^{* *}$ & .000 & $.976^{* *}$ & .000 & $.999^{* *}$ & .000 \\
\hline S-HDL-C(mg/dl) & $.993^{* *}$ & .000 & $.956^{* *}$ & .000 & 1 & & $.992^{* *}$ & .000 & $.954^{* *}$ & .000 \\
\hline S-LDL-C(mg/dl) & $.994^{* *}$ & .000 & $.976^{* *}$ & .000 & $.992^{* *}$ & .000 & 1 & & $.973^{* *}$ & .000 \\
\hline S-VLDL-C(mg/dl) & $954^{* *}$ & .000 & $.999^{* *}$ & .000 & $.954^{* *}$ & .000 & $.973^{* *}$ & .000 & 1 & \\
\hline
\end{tabular}

Serum TC was positively correlated with serum TG and the correlation was statistically significant. Serum TC was positively correlated with serum HDL-C and the correlation was statistically significant. Serum TC was positively correlated with serum LDL-C and the correlation was statistically significant. Serum TC was positively correlated with serum VLDL and the correlation was statistically significant.

In the patients group there was a significant positive correlation between pancreatic alpha amylase and total cholesterol $\left[\mathrm{r}=0.746^{* *}, \mathrm{p}=0.000\right]$. Serum Triglycerides $\left[\mathrm{r}=0.857^{* *}, \mathrm{p}=0.000\right]$. High density lipoprotein- cholesterol (HDL-C), $\left[\mathrm{r}=0.772^{* *}, \mathrm{p}=0.000\right]$, low density lipoprotein-cholesterol $\left[\mathrm{r}=0.789^{* *}, \mathrm{p}=0.000\right]$ and very low density lipoprotein [ $\left.\mathrm{r}=0.860^{* *}, \mathrm{p}=0.000\right]$. C-reactive protein - CRP (mg/l) showed no significant correlation. Approximately $65 \%$ of patients had high pancreatic alpha amylase levels in bile gallbladder. The mean total cholesterol, TG, HDL-C, LDL-C and VLDL-C levels were significantly higher in the acute cholesystitis (AC) in bile patients compared to the serum them patients. 
Table 5: Show mean value \pm SD of liver enzymes AST, ALT, ALP (U/l), and total bilirubin (mg/dl) in bile and serum.

\begin{tabular}{|c|c|c|c|}
\hline Parameter & $\begin{array}{c}\text { Bile } \\
\mathrm{n}=103\end{array}$ & $\begin{array}{c}\text { Serum } \\
\mathrm{n}=103\end{array}$ & $\rho$ Value \\
\hline AST (U/l) & $400.13 \pm 390.44$ & $22.17 \pm 8.90$ & .000 \\
\hline ALT(U/l) & $52.59 \pm 48.04$ & $16.61 \pm 6.73$ & .000 \\
\hline ALP(U/l) & $157.37 \pm 149.66$ & $84.84 \pm 22.78$ & .000 \\
\hline Total bilirubin (mg/dl) & $3.84 \pm 2.94$ & $.282 \pm .22$ & .000 \\
\hline
\end{tabular}

The mean concentration of bile AST was significantly higher than serum AST. The mean concentration of bile ALT was significantly higher than serum ALT. The mean concentration of bile ALP was significantly higher than serum ALP. The mean concentration of bile total bilirubin was significantly higher than serum total bilirubin. $\rho$ Value $(0.000)$.

Table 6: Correlation of serum liver enzymes AST, ALT, ALP (U/l), and total bilirubin (mg/dl), in all patients' cases.

\begin{tabular}{|c|c|c|c|c|c|c|c|c|}
\hline \multirow{2}{*}{ Parameter } & \multicolumn{2}{|c|}{ S-AST } & \multicolumn{2}{c|}{ S-ALT } & \multicolumn{2}{c|}{ S-ALP } & \multicolumn{2}{c|}{ S- TBIL } \\
\cline { 2 - 9 } & $\mathrm{r}$ & $\mathrm{P}-\mathrm{V}$ & $\mathrm{r}$ & $\mathrm{P}-\mathrm{V}$ & $\mathrm{r}$ & $\mathrm{P}-\mathrm{V}$ & $\mathrm{r}$ & $\mathrm{P}-\mathrm{V}$ \\
\hline S-AST (U/l) & 1 & & $.991^{* *}$ & .000 & $.986^{* *}$ & .000 & $.724^{* *}$ & .000 \\
\hline S-ALT (U/l) & $.991^{* *}$ & .000 & 1 & & $.995^{* *}$ & .000 & $.721^{* *}$ & .000 \\
\hline S-ALP (U/l) & $.986^{* *}$ & .000 & $.995^{* *}$ & .000 & 1 & & $.715^{* *}$ & .000 \\
\hline S-TBIL (mg/dl) & $.724^{* *}$ & .000 & $.721^{* *}$ & .000 & $.715^{* *}$ & .000 & 1 & \\
\hline
\end{tabular}

Serum AST was positively correlated with serum ALT and the correlation was statistically significant. Serum AST was positively correlated with serum ALP and the correlation was statistically significant. Serum AST was positively correlated with serum T BIL and the correlation was statistically significant

Our study showed that the abnormal biochemical liver function test of almost all patients resolved rapidly and spontaneously after cholecystectomy and indicates that there is an acute hepato-cellular injury in symptomatic gallstones with cholecystitis in the absence of common bile duct stones and this injury is mild and transient (AST) $\left[\mathrm{r}=0.923^{* *}, \mathrm{p}=0.000\right]$, alanine aminotransferase (ALT) $\left[\mathrm{r}=0.953^{* *}, \mathrm{p}=0.000\right]$, alkaline phosphatase (ALP) [r=0.900**, $\mathrm{p}=0.000]$, and bilirubin total (TBIL) [r=0.932**, $\mathrm{p}=0.000]$.

Patients without significant pancreatic-biliary reflux (PBR) had normal bile levels of pancreatic enzymes (such as amylase). In recent investigation, patients without gallstones showed very low or absence of pancreatic enzymes in their gallbladder bile. Lipid profile did not show significant changes in female patients whereas in male patients levels of cholesterol and triglycerides are increased. Liver function tests showed that AST, ALT and ALP levels are elevated in patients with AC especially in bile of these patients. Therefore, increase in bile levels of amylase along with elevations in liver enzymes may help in early detection of AC. There was significant association between age of the patients and bile amylase levels.

Table 7: Show mean value \pm SD of liver enzymes AST, ALT, ALP (U/l), and total bilirubin (mg/dl) in bile and serum.

\begin{tabular}{|c|c|c|c|}
\hline Parameter & $\begin{array}{c}\text { Bile } \\
\mathrm{n}=103\end{array}$ & $\begin{array}{c}\text { Serum } \\
\mathrm{n}=103\end{array}$ & $\rho$ Value \\
\hline AST $(\mathrm{U} / \mathrm{l})$ & $400.13 \pm 390.44$ & $22.17 \pm 8.90$ & .000 \\
\hline $\mathrm{ALT}(\mathrm{U} / \mathrm{l})$ & $52.59 \pm 48.04$ & $16.61 \pm 6.73$ & .000 \\
\hline $\mathrm{ALP}(\mathrm{U} / \mathrm{l})$ & $157.37 \pm 149.66$ & $84.84 \pm 22.78$ & .000 \\
\hline Total bilirubin $(\mathrm{mg} / \mathrm{dl})$ & $3.84 \pm 2.94$ & $.282 \pm .22$ & .000 \\
\hline
\end{tabular}

The mean concentration of bile AST was significantly higher than serum AST. The mean concentration of bile ALT was significantly higher than serum ALT. The mean concentration of bile ALP was significantly higher than 
Biochemical Studies Related to Acute Cholecystitis in Libyan Subjects

serum ALP. The mean concentration of bile total bilirubin was significantly higher than serum total bilirubin. $\rho$ Value (0.000).

Table 8: Correlation between CRP (mg/l), lipid profile TC, TG, HDL-C, LDL-C and VLDL cholesterol (mg/dl) serum and bile pancreatic alpha amylase, and total amylase in serum and bile of all patient's cases.

\begin{tabular}{|c|c|c|c|c|c|c|c|c|c|}
\hline \multirow[t]{2}{*}{ Parameter } & & \multicolumn{2}{|c|}{ S-Pancreatic $\alpha$ Amyl } & \multicolumn{2}{|c|}{ B-pancreatic $\alpha$ Amyl } & \multicolumn{2}{|c|}{ S- Total Amyl } & \multicolumn{2}{|c|}{ B- Total Amyl } \\
\hline & & $\mathrm{R}$ & $\mathrm{P}-\mathrm{V}$ & $r$ & $\mathrm{P}-\mathrm{V}$ & $r$ & $\mathrm{P}-\mathrm{V}$ & $\mathrm{r}$ & $\mathrm{P}-\mathrm{V}$ \\
\hline \multirow[t]{2}{*}{ CRP (mg/l) } & $S$ & $.588^{* *}$ & .000 & $.456^{* *}$ & .000 & $.612^{* *}$ & .000 & $.539^{* *}$ & .000 \\
\hline & B & .119 & .232 & .116 & .244 & .185 & .061 & .096 & .336 \\
\hline \multirow[t]{2}{*}{$\mathrm{TC}(\mathrm{mg} / \mathrm{dl})$} & $\mathrm{S}$ & $.968^{* *}$ & .000 & $.746^{* *}$ & .000 & $.979^{* *}$ & .000 & $.905^{* *}$ & .000 \\
\hline & B & $.963^{* *}$ & .000 & $.918^{* *}$ & .000 & $.935^{* *}$ & .000 & $.995^{* *}$ & .000 \\
\hline \multirow[t]{2}{*}{$\mathrm{TG}(\mathrm{mg} / \mathrm{dl})$} & $S$ & $.986^{* *}$ & .000 & $.857^{* *}$ & .000 & $.987^{* *}$ & .000 & $.972^{* *}$ & .000 \\
\hline & $\mathrm{B}$ & $.924^{* *}$ & .000 & $.953^{* *}$ & .000 & $.905^{* *}$ & .000 & $.984^{* *}$ & .000 \\
\hline \multirow[t]{2}{*}{ HDL-C(mg/dl) } & $S$ & $.966^{* *}$ & .000 & $.772^{* *}$ & .000 & $.977^{* *}$ & .000 & $.916^{* *}$ & .000 \\
\hline & B & $.932^{* *}$ & .000 & $.921^{* *}$ & .000 & $.901^{* *}$ & .000 & $.982^{* *}$ & .000 \\
\hline \multirow[t]{2}{*}{ LDL-C (mg/dl) } & $S$ & $.979^{* *}$ & .000 & $.789^{* *}$ & .000 & $.990^{* *}$ & .000 & $.932^{* *}$ & .000 \\
\hline & B & $.921^{* *}$ & .000 & $.947^{* *}$ & .000 & $.891^{* *}$ & .000 & $.983^{* *}$ & .000 \\
\hline \multirow[t]{2}{*}{ VLDL (mg/dl) } & $S$ & $.986^{* *}$ & .000 & $.860^{* *}$ & .000 & $.987^{* *}$ & .000 & $.974^{* *}$ & .000 \\
\hline & $\mathrm{B}$ & $.947^{* *}$ & .000 & $.951^{* *}$ & .000 & $.931^{* *}$ & .000 & $.994^{* *}$ & .000 \\
\hline
\end{tabular}

\section{DISCUSSION}

Cholecystitis is inflammation of the gallbladder that develops over hours, usually because a gallstone obstructs the cystic duct, if it develops slowly overtime it is called chronic cholecystitis. Symptoms include right upper quadrant pain and tenderness, sometimes accompanied by fever, chills nausea and vomiting. [3]. In a study done by Geraghty and Goldin in 1994, they stated that there were high proportion (66\%) of patients with gallstones and cholecystitis having abnormal liver histology. [4] The most common findings were non-specific reactive hepatitis and large droplet fatty change. Cholecystitis should be regarded as a cause of reactive hepatitis. Some patients with reactive hepatitis had acute inflammatory cells in the portal tracts and that correlated with acute inflammation in the gallbladder

Analyses of frequency showed that acute cholecystitis was more common in females than males with percent (9\% male and $91 \%$ female) witch approximately fold higher in females, this finding similar to previous finding that, out of 904 study population the predominantly are female which account of 798 (88\%), and $106(12 \%)$ were male. ${ }^{5}$ The Sphincter of Oddi, which regulates the outflow of bile and pancreatic secretions, is deficient inanomalous union of the pancreatic biliary duct (AUPBD) due to the long common channel, allowing two-way regurgitation. Pancreatic biliary reflux can result in various pathological conditions including choledocholithiasis, cholangitis, gallstones, acute pancreatitis, bile duct cancer, gallbladder cancer, and pancreatic ductal carcinoma. [6]

In the present study showed, that bilirubin total concentration was highest in biliary and lowest in serum. It was significantly higher in biliary compared to serum $(\mathrm{p}<0.01)$. The finding of bacterial proteins in stones, therefore, confirms these observations. The ability of bacterial $\beta$-glucuronidase enzymes to hydrolyse the bilirubin glucuronide complex thus releasing a poorly soluble bilirubin has been proposed to explain the formation of pigment stones. [7], [8]

We Showed ALP, AST, ALT, and T. BILI were high mean significantly increased in biliary males and positive high correlation more than compared females biliary. Abnormal liver function tests were most common in patients with choledocholithiasis. An obstructive pattern with raised alkaline phosphatase values was the most frequent abnormality, which was similar to the findings of others [9]

Our results LFT parameter in this study showed increased in AST, ALT, ALP and bilirubin total levels are in agreement with Peng et al., 2005 findings. [10] When levels were greatly increased, all parameters were specific in predicting the presence of bile duct stones. However, that bilirubin showed an early breakdown, indicating that at a lower cut-off value bilirubin is no longer specific in predicting CBD stones. Evaluating role of liver enzymes in 
prediction of extra liver obstruction in patients will delay diagnosis of CBD stone. They found that serum level of bilirubin was the best predictor CBD stenosis due to stone or malignancy. In our study serum level of bilirubin had higher none significant difference between three study groups compared to biliary levels. [11], [12] As expected, the bilirubin content was highest in pigment stones (PS). This has been demonstrated in many earlier studies. The bilirubin in these stones is mostly unconjugated because the conjugated form is water soluble and excreted through bile. Decreased secretion of biliary acids, increased secretion of unconjugated bilirubin into the bile, and infection of the biliary tract are the most important causative factors. [2] That bile duct obstruction due to stones results in a typical cholestatic biochemical profile, with a greater rise in ALP than transaminases. Increases AST were likely to equal or exceed raise ALP in common bile duct stone patients. The possibility of extra hepatic biliary obstruction should not be overlooked when AST is the predominantly elevated enzyme. In particular, if pain is associated with a hepatic pattern of LFTs obstructing biliary stones should be suspected, although pain associated with jaundice should always suggest gallstone disease, high AST levels, at peak hyperbilirubinaemia without biliary pain may be misleading, clinicians may erroneously diagnose a hepatitic illness rather than a cholestatic illness, since grossly elevated AST levels were found. [13] Acute cholecystitis is the most common complication of cholelithiasis. Conversely, about (95\%) of patients with acute cholecystitis have cholelithiasis. When a stone becomes impacted in the cystic duct and persistently obstructs it, acute inflammation results. Bile stasis triggers release of liver enzymes e.g., serum, ALP, AST and ALT along with serum bilirubin level. The gallstones block fluid from passing out of the gallbladder that results in an irritated and swollen gallbladder. [14] These patients had elevated levels of bile transaminases. In a study done by Chen-Wang and his colleagues; he stated that hepatocellular injury, (diagnosed clinically by elevation of aminotransferase and bilirubin levels) was common. The incidence was higher and the aminotransferase elevations were more marked in those with stones, but some patients without CBD stones also had a degree of Hepatocellular injury. [15] Patients with acute calculus cholecystitis had a serum bilirubin level between 2 to $5 \mathrm{mg} / \mathrm{dL}$ with no CBD abnormality. Also, over one third of patients with calculus cholecystitis had an elevated bilirubin level with a normal CBD. [16] In some studies, there is a correlation between the bilirubin concentration and lipid peroxidation in cases of biliary tract diseases, with the presence of interaction between free radical reactions, gallbladder formation and the degree of cholecystitis. [17] It was found in previous study that pigment Stones (PS) was the most common type of gallstones, and cholesterol seemed to be the major component in all types of stones. High cholesterol content in cholesterol stone (CS) specific suggests super saturation of cholesterol in bile consequent to dyslipidemia (excessive cholesterol and altered lipid metabolism) is an etiological factor. Higher triglycerides content in mixed stones also suggests that dyslipidemia plays a key role in its pathogenesis. [18] In the current study positive correlation was observed in TC, TG, HDL, LDL and VLDL. Some investigators found positive association between gallstone disease and increased levels of biliary total cholesterol, Triglycerides, LDL cholesterol, HDL cholesterol and VLDL cholesterol. Interruption of the enter hepatic circulation of bile acid increases serum triglyceride by increasing the production of very low density lipoproteins (VLDL). [19] LDL cholesterol are cleared from the circulation, increased catabolism of LDL cholesterol can fully explain the increased cholesterol secretion into bile, the stimulated LDL cholesterol uptake would in turn had to be explained by an increased cholesterol production [20]. Highly positive significant correlations were found between HDL and total cholesterol. The mean biliary HDL and total cholesterol were higher than in serum lipids, a number of studies have shown that patients with elevated VLDL, triglyceride had higher than normal rates of bile acid synthesis and increased rates of cholesterol synthesis. [21] Total cholesterol, TAG was significantly higher in cholesterol bile, compared to serum $(p<0.001)$. A multitude of factors has been postulated in the formation of gallstones, and amongst them the concept of cholesterol super saturation in the formation of cholesterol gallstone is the most widely accepted one. The cause of cholesterol super saturation is usually due to the hyper secretion of cholesterol into the bile by liver. This may be due to increased DE novo synthesis of cholesterol by the liver; this hypothesis is given ground by some clinical trials in which it was observed that use of statin group of drugs decreases the incidence of gallstone disease. [22] Super saturation of cholesterol can also be due to the defect in bile acid synthesis or metabolism. Cholesterol being a nonpolar molecule is transported in clusters of bile acids called micelles. Increased ratio of cholesterol to bile acid may lead to the bile being supersaturated with cholesterol, thus predisposing to the formation of gallstones. The patients with gallstones under study were classified into two groups depending on their age. The results showed that there was significant $(\mathrm{p}<0.000)$ increase in concentration of cholesterol, TAG, HDL, LDL and VLDL in age group (41-45) significant $(\mathrm{p}<0.000)$, our results are in disagreement with (Al-Saadi et al., 2018). In the present study an increase in bile total cholesterol, TAG, VLDL-C, LDL-C and a decrease HDL-C were observed. It was reported that an increase in 
the dietary cholesterol resulted in an increase in biliary cholesterol secretion in gallstone patient compared to controls suggesting that dietary cholesterol might be important in the pathogenesis of cholesterol gallstones [23] These findings support the hypothesis that hepatic metabolism of cholesterol in gallstone patients differs from those without stones. Low HDL cholesterol and a latrogenic biliary profile, multiple factors may lead to patients to develop cholesterol gallstones and features of the metabolic syndrome. [24] In male patients showed age range (43 to 45), $8 \%$ very high significant correlation between the relative change in biliary lipids and serum were found high positive correlation. Some investigators found a positive association between gallstone disease and increased levels of serum triacylglycerol, LDL cholesterol and increased HDL cholesterol. Our results were show increased TC, TG, LDL cholesterol, V LDL cholesterol and HDL cholesterol in biliary levels positive very high significant $(\rho$ Value $=.000)$ and positive strong correlation compared to serum. Our study demonstrates that high mean level of bile triglycerides. Lipid comparison of biliary and serum showed mean that the concentration of total cholesterol was about two times more than that in the serum. Lipid comparison of biliary and serum showed mean that the concentration of TAG was two times more than that in the serum. Lipid comparison of biliary and serum showed mean that the concentration of LDL-C was about three times more than that in the serum. Lipid comparison of biliary and serum showed mean that the concentration of HDL cholesterol was increased abnormality in the serum. Endogenous hypertriglyceridemia is a multifactorial disorder of very low density lipoprotein (VLDL) metabolism, resulting in elevated serum triglyceride (TAG) concentrations and high levels of high density lipoprotein (HDL) cholesterol. Hypertriglyceridemia is associated with cardiovascular disease which is prevalence in males higher than females. This suggests that changes in serum lipid profile are a possible consequence of the presence of gallstones, especially through biliary obstruction. Biliary cholesterol saturation is increased in obesity ${ }^{24}$ and hypertriglyceridemia is frequently accompanied by obesity. [25] Supersaturated bile in hypertriglyceridemia may be related to the presence of obesity rather than to hypertriglyceridemia itself. To date, it is not known whether gallbladder motility contributes to the increased risk of cholelithiasis to hypertriglyceridemia. In female were studied, rang of age 20 to 42 years. Seem to be in accordance with the findings of other investigators who had reported. Women had smaller total bile acid pools and increased biliary cholesterol content that predisposes them to super saturation of cholesterol in the bile pool, resulting in gallstone formation. ${ }^{26} \mathrm{We}$ found positive correlation significance between of bile and serum in TC, TAG, LDL, and VLDL. Our results were quite contrary to the findings of Nadeem et al. ${ }^{24} \mathrm{High}$ cholesterol in bile as compared to bile acids and bile salts leads to nucleation of cholesterol which results in the development of gall stones. ${ }^{25}$. Schirmer has also reported that cholelithiasis is more common in females higher than males, while the incidence becomes equal in both gender in older age. [26] The present study had showed serum female HDL cholesterol higher than level compared to bile patients and was very high significantly increased ( $\rho$ Value $=.000$ ). Other study is in disagreement in accordance with the findings in (Naseem et al., 2010). Current study showed that in gallstone disease (GD) patients the serum levels of HDL cholesterol was high compared to bile patients an unusual observation which could be a result of poor hepatic uptake of HDL cholesterol in GD patients, our results were in agreement with (Jaraari et al., 2010). Among female patients had gallstones, bile lipids levels (total cholesterol, triglyceride, high density lipoprotein cholesterol were higher than compared to serum except serum very low density lipoprotein levels was higher than compared to bile biliary very high significant and positive very strong correlation. In comparison between serum lipids and biliary lipids, in our study the mean of serum cholesterol were not high in females $(138.85 \mathrm{mg} / \mathrm{dl})$.

In our study patients male and females showed prevalence of cholecystitis increasing with age were male higher than compared to females. Cholesterol gallstones occur more frequently in women than in men in every population examined; the present study clearly demonstrates that the effect of exogenous estrogens on biliary lipid composition is the consequence of an increased secretion of cholesterol, and not of a decreased secretion of bile acids. [27] We demonstrated that the ratio of females was higher ratio of males, and this finding is consistent with several similar studies. [28] This difference between the sexes begins during puberty and continues through the fertile years, focusing attention on the effects of female sex hormones. Cholecystitis and cholelithiasis are very common particularly in fatty, fertile and female in their forties. It is prevalence varies with age, sex and ethnic group. [29] We suggest the reason in males were biliary TAG, TC, HDL, and LDL were higher than female. The scavenger receptor, class B type 1 (SR-B1), is multi ligand membrane receptor protein that functions as a physiologically relevant highdensity lipoprotein (HDL) receptor whose primary role is to mediate selective uptake or influx of HDL derived cholesterol esters into cells and tissues. SR-B1 also facilitates the efflux of cholesterol from peripheral tissues, including macrophages, back to liver. [30] Biliary lipid absorption by the gall bladder mucosa and the cholesterol 
content of the gall bladder wall appear to play a role in cholesterol gall stone formation. As the scavenger receptor class B type I (SR- BI) regulates cellular cholesterol uptake, we studied its expression in human and murine gall bladders, its regulation by increased biliary lipid content, and its role in gall stone formation, abnormalities of serum lipoprotein metabolism are known to affect biliary cholesterol secretion [31]. In our results finding mean of serum TC, TAG, LDL and VLDL in male were higher than female, in comparison of lipids between males and females, serum HDL were higher in males than females. Schirmer has reported that cholelithiasis is more common in females higher than males, with female to male ratio of about (4:1), while the incidence becomes equal in both genders in older age. This may be because of the basic hormonal differences between males and females, together with the differences that might exist due to co-expression of sex hormone receptors in the gallbladder of both [31] The present study showed demonstrates a correlation of serum and biliary lipid profiles with gallstones in Libyan population, our results were in agreement with the previous studies. [32] Acute cholecystitis (AC) is a syndrome which entails the continuation of clinic pathological states; one end of this range is acute cholecystitis. In our study showed elevated serum CRP level compared to bile, and observed significantly associated with patients having cholecystitis. Some studies reported that CRP cannot play a suitable role in cholecystitis diagnosis, but can be a factor indicating the severity of cholecystitis usually, pain of the acute cholecystitis is constant and severe with some associated symptoms of including anorexia and vomiting or nausea along with the history of fatty food intolerance estimated $>1$ hour before the early onset of the pain. [33] CRP up to $2 \mathrm{mg} / \mathrm{L}$ because severity of inflammation does not influence the LFT's parameters and this is comparable with our results (Peng et al., 2005). The study by Juvonen et al. showed that large increases in CRP were associated with both infected bile and gangrene of the gallbladder. The Tokyo guidelines have used CRP of $>3 \mathrm{mg} / \mathrm{L}$ as one of the diagnostic criteria but have not used it with different cut-offs for diagnosing severity [34] In patients of acute cholecystitis with high levels of CRP, conversion from laparoscopic to open procedure was found to be at higher rates, Prediction of the grade of acute cholecystitis by plasma level of Creactive protein (Kabul et al., 2015).

\section{CONCLUSION}

Patients with acute cholecystitis show abnormal increase in levels of alpha amylase both in blood and bile samples if patients taken for our study.

It appears that estimation of serum or bile amylase could be added as diagnostic biomarker for patients with $\mathrm{AC}$, taking patient's case history into consideration (Classic mantra of fat, forty, fertile, and flatulent) and possibly ruling out acute pancreatitis.

Routine investigation of bile pancreatic alpha amylase in patient having cholecystitis can be used as method for early detection of cancer lesions.

Reason why such levels of pancreatic alpha enzymes are refluxed into biliary tree and gallbladder in patients with gallbladder disease should be clarified by further research and wider scale study.

Our study shows abnormal biochemical liver function test of almost patients after cholecystectomy and indicates the presence of acute hepatocellular injury in patients with symptomatic gallstones with cholecystitis in absence of common bile duct stones.

\section{SOURCES OF FUNDING}

This research received no specific grant from any funding agency in the public, commercial, or not-for-profit sectors.

\section{CONFLICT OF INTEREST}

The author have declared that no competing interests exist. 
Biochemical Studies Related to Acute Cholecystitis in Libyan Subjects

\section{ACKNOWLEDGMENT}

We express our thanks to the staff and residents of the Department of Surgery, AL-Jalaa Surgery and Accidental Hospital, Benghazi Medical Center (BMC), Ibnsina Clinic Benghazi and Medical Services Center - University of Benghazi / Medical Laboratory for providing samples and relevant information about patients.

\section{REFERENCES}

[1] JARAARI, A. M., JAGANNADHARAO, P., PATIL, T. N., HAI, A., AWAMY, H. A., EL SAEITY, S. O., ABDEL KAFI, E. B., EL-HEMRI, M. N. \& TAYESH, M. F. Quantitative analysis of gallstones in Libyan patients. Libyan J Med,2010; 5.

[2] PEELA JAGNNADHA RAO, ABDALLA JARARI, HAYAM El AWAMI, TN PATIL. Lipid Profile in Bile and Serum of Cholelithiasis Patients- A Comparative Study. Journal of Basic Medical and Allied Sciences;2010;1(2).

[3] PADDA, M. S. et al. '. Liver test patterns in patients with acute calculous cholecystitis and/or choledocholithiasis', Alimentary Pharmacology and Therapeutics, 2009;29: 1011-1018.

[4] HENRY JB. Clinical diagnosis and management by laboratory methods, 17 th ed. WB Saunders Company, Philadelphia, 2001;217-250.

[5] GERAGHTY JM, GOLDIN RD. 1994. Liver changes associated with cholecystitis. J. Clin. Pathol.; 47(5):457-460.

[6] NAKEEB, A., COMUZZIE, A. G., MARTIN, L., SONNENBERG, G. E., SWARTZ-BASILE, D., KISSEBAH, A. H., \& PITT, H. A. Gallstones: Genetics versus Environment. Annals of Surgery, 2002;235: 842-849.

[7] SUK KEU YEOM, SEUNG WHA LEE, SANG HOON CHA, HWAN HOON CHUNG, BO KYUNG JE, BAEK HYUN KIM, JONG JIN HYUN. Biliary reflux detection in anomalous union of the pancreatico-biliary duct patients. Division of Gastroenterology and Hepatology 2012;18(9): 952-959.

[8] El HAJJ, I. I. et al. 'Idiopathic Acute Pancreatitis And Acute Recurrent Pancreatitis'2001: 96(9).

[9] ElfERINK, R. P., TYTGAT, G. N. \& GROEN, A. K. Hepatic canalicular membrane 1: The role of mdr2 Pglycoprotein in hepatobiliary lipid transport. FASEB J1997;11: 19-28.

[10] ELGHAWY, K. et al. 'A case of duodenal adenocarcinoma masquerading as acute cholecystitis and biliary pancreatitis', Case Studies in Surgery, 2016;2(2).

[11] ERIKSSON, M., BERGLUND, L., RUDLING, M., HENRIKSSON, P. \& ANGELIN, B. Effects of estrogen on low density lipoprotein metabolism in males. Short-term and long-term studies during hormonal treatment of prostatic carcinoma. J Clin Invest,1989;84, 802-10

[12] AYDOGDU, I., SARI, R., ULU, R., and SEVINC, A. The frequency of gallbladder stones in patients with pernicious anemia. J Surg Res2001; 101:120-3.

[13] BUCH, S., SCHAFMAYER, C., VOLZKE, H., SEEGER, M., MIQUEL, J.F., SOOKOIAN S.C., et al. Loci from a genomewide analysis of bilirubin levels are associated with gallstone risk and composition. Gastroenterology; 2010; 139:1942-51.

[14] GERAGHTY JM, GOLDIN RD.. Liver changes associated with cholecystitis. J. Clin. Pathol.; 1994;47(5):457-460.

[15] PENG, W. K. et al. 'Role of liver function tests in predicting common bile duct stones in acute calculous cholecystitis', British Journal of Surgery, 2005; pp. 1241-1247.

[16] ZARE MOHAMMAD, KARGAR SAEED, AKHONDI MOHSEN, and MIRSHAMSI MOHAMMAD HUSSEIN. Role of Liver Function Enzymes in Diagnosis of cholithiasis in Biliary Colic Patients. Acta Medica Iranica,; 2011;49(10): 663-666.

[17] KARAVONE J, KARISTO V, GRONROOS J. 2006. Stone or stricture as a cause of extrahepatic cholestasis: do liver function tests predict the diagnosis? Clin Chem Lab Med;44(12):1453-6.

[18] HAYAT J.O., LOEW C.J., ASRRESS K.N., MCINTYRE A.S. and GORARD D.A. Contrasting liver function test patterns in obstructive jaundice due to biliary structures and stones. Q J Med; 2005; 98:35-40.

[19] CHEN W C, WEN HC, CHING CL, CHENG HC, TSARG EW, SHOU CS. Acute transient hepatocellular injury in cholelithiasis and cholecystitis without evidence of choledocholithiasis. World J. Gastroenterol. 2009; 15 (30): 3788- 3792.

[20] KURZWEIL SM, SHAPIRO MJ, ANDRUS CH, WITTGEN CM, HERMANN VM, KAMNSKI DL. Hyperbilirubinemia without CBD abnormalities and hyperamylasemia without pancreatitis in patients with gallbladder disease. Arch. Surg. 1994;128(8): 829-833. 
Abdalla M Jarari, Abdelaziz MA AlFaydi, Nouh MH Aljarari, Saeid Omar Al Soaeiti, Ibtisam Cheith Kaziri, and Dhastagir Sultan Sheriff

[21] FEHER G, LENGYEL G, BLA-ZOVICA Oxidative stress in the liver and diseases. Scand J Gastroenterol.1998; 228: 38-46.

biliary tract

[22] PERERA, M. et al..'A Case of Concomitant Perforated Acute Cholecystitis and Pancreatitis', Case Reports in Surgery, 2013, pp. 1-3.

[23] LONARDO, A., LOMBARDINI, S., SCAGLIONI, F., BALLESTRI, S., VERRONE, A. M., BERTOLOTTI, M., CARULLI, L., GANAZZI, D., CARULLI, N. \& LORIA, P. Fatty liver, carotid disease and gallstones: a study of age-related associations. World J Gastroenterol,2006; 12, 5826-33.

[24] BEIL, U., GRUNDY, S. M., CROUSE, J. R. \& ZECH, L.. Triglyceride and cholesterol metabolism in primary hypertriglyceridemia. Arteriosclerosis, 1982;2, 44-57.

[25] ERIKSSON, M., BERGLUND, L., RUDLING, M., HENRIKSSON, P. \& ANGELIN, B. 1989. Effects of estrogen on low density lipoprotein metabolism in males. Short-term and long-term studies during hormonal treatment of prostatic carcinoma. J Clin Invest, 1989; 84, 802-10.

[26] ANGElin, B., OLIVECRONA, H., REIHNER, E., RUDling, M., STAHLBERG, D., ERIKSSON, M., EWERTH, S., HENRIKSSON, P. \& EINARSSON, K. . Hepatic cholesterol metabolism in estrogen-treated men. Gastroenterology,1992; 103, 1657-63.

[27] BEIL, U., GRUNDY, S. M., CROUSE, J. R. \& ZECH, L. Triglyceride and cholesterol metabolism in primary hypertriglyceridemia. Arteriosclerosis, 1982;2, 44-57.

[28] CHANDRAN P, GARG P, PUNDIR CS. Correlation between chemical components of billary calculi and bile \& sera and bile of gallstone patients. Indian Journal of clinical biochemistry. 2005 Jul; 20(2):81-5.

[29] AHMED, H. A., JAZRAWI, R. P., GOGGIN, P. M., DORMANDY, J. \& NORTHFIELD, T. C. Intrahepatic biliary cholesterol and phospholipid transport in humans: effect of obesity and cholesterol cholelithiasis. J Lipid Res, 1995;36, 2562-73.

[30] GRUNDY, S. M.Hypertriglyceridemia, atherogenic dyslipidemia, and the metabolic syndrome. Am J Cardiol,1998; 81, 18B-25B.

[31] NASEEM A.C., FATEHUDDIN, K., ALLAH, B. G., \& ALI, M., S., Quantitative Analysis of Serum Lipid Profile in Gallstone Patients and Controls Pak. J. Anal. Environ. Chem. 2010Vol. 11, No. 1 ISSN-1996-918X 59.65

[32] PANI J.P, PANDEY M S, PANI D S, MADERAKAR M N and KATTI H K., Estimation of predominate histologic alterations in cholecystitis and cholithiasis of human gallbladder an analytical and statistical study through the approach of routine histochemistry. IOSR Journal of Dental and Medical Sciences. 2013;6(6):35-43.

[33] MIQUEL, J. F., MORENO, M., AMIGO, L., MOLINA, H., MARDONES, P., WISTUBA, II, \& RIGOTTI, A. . Expression and regulation of scavenger receptor class B type I (SR-BI) in gall bladder epithelium. Gut, 2003;52(7), 10171024.

[34] SCHIRMER, B.D., WINTERS, K.L. A and EDLICH, R.F. 2005.Cholelithiasis and cholecystitis. Journal of LongTerm Effects of Medical Implants.;15 (3): 329-38.

[35] PENG, W. K. et al.. 'Role of liver function tests in predicting common bile duct stones in acute calculous cholecystitis', British Journal of Surgery, 2005;pp. 1241-1247.

[36] JULIUS L. TOTH, P. ROBERT C. HARVEY, G. ARAMNDA UPADYHA AND STEVEN M. STRASEERG. 1990. Albumin Absorption and Protein Secretion by the Gallbladder in Man and in the Pig. (HEPATOLOGY 1990; 12: 729737). 